\title{
Effect of Different Planting Dates on Growth and Development of Gladiolus grandiflorus under the Ecological Conditions of Faisalabad, Pakistan
}

\author{
Muhammad Adil ${ }^{1, *}$, Waqas ahmad ${ }^{1}$, Khawaja Shafique Ahmad ${ }^{2}$, Jamil Shafi ${ }^{3}$, Muhammad Asif Shehzad ${ }^{4}$, \\ Muhammad Aqeel Sarwar ${ }^{4}$, Muhammad Salman ${ }^{5}$, Muhammad Imran Ghani ${ }^{1}$, Muhammad Iqabal ${ }^{1}$ \\ ${ }^{1}$ Institute of Horticultural Sciences, University of Agriculture, Faisalabad (38040) Pakistan \\ ${ }^{2}$ Department of Botany, University of Agriculture Faisalabad (38040) Pakistan \\ ${ }^{3}$ Department of Plant Pathology, University of Agriculture, Faisalabad (38040) Pakistan \\ ${ }^{4}$ Department of Agronomy, University of Agriculture, Faisalabad (38040) Pakistan \\ ${ }^{5}$ Department of Plant Breeding and Genetics, University of Agriculture, Faisalabad (38040) Pakistan \\ *Corresponding email: floricultureuaf@gmail.com
}

Copyright (C) 2013 Horizon Research Publishing All rights reserved.

\begin{abstract}
The present study was carried out to elucidate the effect of different sowing dates and temperature on growth, yield and quality of two important cultivars of Gladiolus grandiflorus L. Rose supreme and White prosperity. The results showed that different planting dates have significant effect on number of days taken by gladiolus corm to germinate. A significant superiority of $T_{1} 5.5$ days over $\mathrm{T}_{2}$ with 9.10 days on all the treatments was observed. Among the treatments maximum sprouting percentage was recorded in $\mathrm{T}_{2}$ with $94.66 \%$ followed by $\mathrm{T}_{3} 82.19 \%$ on all the treatments. The days to 6-leaves stage depict highly significant difference in variance of treatments, interactive effect of treatments and cultivars. The maximum plant height $(115.33 \mathrm{~cm})$ was recorded in $\mathrm{T}_{2}$ followed by $\mathrm{T}_{3}$ with $111.04 \mathrm{~cm}$. Mean values of number of leaves indicated significant superiority of $T_{2}$ with 8.02 leaves and $T_{3}$ with 7.93 leaves on all other treatments. The maximum chlorophyll contents 71.60 were recorded in $T_{2}$ followed by $\mathrm{T}_{3}$ with 67.65 on all the treatments. Spike length showed highly significant difference in variance of treatments, interactive effect of treatments and cultivars. The maximum number of florets (17.16) was recorded in $T_{2}$ followed by $T_{3}$ with 15.83 florets. Among the treatments maximum corm diameter $(6.19 \mathrm{~cm})$ was recorded on $\mathrm{T}_{2}$ and $\mathrm{T}_{6}$ showed maximum number of cormels $(5.96 \mathrm{~cm})$. It is suggested that proper planting date reduce the production cost by reducing the crop time and also produce elite flowers with increased market value.
\end{abstract}

Keywords Planting dates, Gladiolus grandiflorus, Temperature, Yield

\section{Introduction}

Floriculture has emerged as a potential business in Pakistan. The most important floricultural crops in the Pakistan cut flowers trade are Roses, Gladiolus, Tuberoses, Iris, Narcissus, Lilies, Freesia, Statice and Gerbera. Production of cut flowers in Pakistan is estimated at about 10-12 thousand tons per annum and floriculture is fast emerging as a profitable venture for small farmers [1].

Gladiolus (Gladiolus grandiflorus) is an ornamental plant native to South Africa. It belongs to monocot family Iridaceae, having approximately one hundred and fifty known species [2]. This plant is commercially used for cut flowers and occasionally used for landscape purpose. Gladiolus is one of the few plants which produce pleasant cut flowers with long spikes. It is cultivated in most of the tropical and subtropical countries of the world [3].

Varied agro-climatic conditions in Punjab could allow commercial cultivation of all varieties of Gladiolus either in open field or under green house conditions. However, the commercial cultivation of Gladiolus in the country has so far been restricted to limited areas of the province mainly due to domestic market for these flowers. Comprehensive survey indicates that Gladiolus is next to roses in preference by the consumers in various cities of the Punjab. The total area under flower in Punjab Province is estimated around 9000 acres, under flower farming such as Roses, Gladiolus, tuberoses and jasmine. Over 450 acres are under the cultivation of Gladiolus in Punjab [4]. Pakistan has export potential in the global markets like United Arab Emirates (UAE), Saudi Arabia, Russian Federation and European Union [5].

Date of planting plays an important role in regulating growth and quality of gladiolus. Vegetative growth and quality of gladiolus is improved by proper planting times which also satisfy the consumer's demands [6]. Different 
planting schedule supply gladiolus steadily to the market as well as it adds to the beauty of the landscape longer. The timing of flowering from various planting dates is quite predictable under ideal environmental conditions. The growth and yield of Gladiolus like other plants depend upon planting time e.g., number of florets/spike, spike length, floret diameter, floret length was best with earliest planting [7].

Light, temperature and water are all important in flowering of gladiolus. Planting schedule vary because of differences in photoperiods, temperatures and light intensity. Light is the major contributor to growth and development of Gladiolus. Two assimilate sinks exist; the inflorescence and corms, and these are greatly affected by photoperiod [8]. Gladiolus as most common flowering plant, prefer a growing location in full sun for most of the day. Both the presence and absence of light greatly affects flower development. Flowering of gladiolus is controlled partially by day length provided temperatures are in the proper range.

The present research work was planned to investigate the growth and flowering of gladiolus in early and late growing season and to study its correlation with temperature under agro-ecological conditions of Faisalabad Pakistan and to establish a protocol for off-seasoning which is commercially feasible and easily adoptable with minimum capital investment.

\section{Materials and Methods}

The Present study was conducted at Floriculture Research Area, Institute of Horticultural Sciences, University of Agriculture, Faisalabad, Pakistan, during 2010-11. The study was carried out to elucidate the effect of different sowing dates and temperature on growth, yield of two important cultivars of Gladiolus grandiflorus L. Rose supreme and White prosperity in field under the Agro-Ecological conditions of Faisalabad, Punjab, Pakistan.

Growth parameters such as, days to germination, sprouting percentage, days to 6-leaves stage, plant height (cm), number of leaves and chlorophyll content (spad value) were determined. Flowering parameters such as, days to spiking, length of spike $(\mathrm{cm})$, diameter of spike $(\mathrm{cm})$, diameter of florets $(\mathrm{mm})$, number of floret spike per plant, fresh weight of spike $(\mathrm{g})$, dry weight of spike $(\mathrm{g})$, corms parameters, diameter of corms $(\mathrm{mm})$, weight of corms $(\mathrm{g})$, number of cormels and weight of cormels (g) were computed.

\subsection{Statistical Analysis}

The data was analyzed statistically by using analysis of variance technique and treatment means were compared in two factorial Randomized complete block design (RCBD) at $5 \%$ level of significance [9]. The relation of the different growth parameters and temperature were assessed through regression, co-relation analysis.

\section{RESULTS}

\subsection{Soil Analysis}

Soil analysis showed that soil has normal electrical conductivity (EC) $2.05 \mathrm{dS} \mathrm{m}^{-1}$ and high $\mathrm{pH}$ (8.08). The amount of organic matter was also low $(0.505 \%)$. Potassium contents (195 mg kg $\mathrm{mg}^{-1}$ ) were in normal range while phosphorus contents $\left(8.2 \mathrm{mg} \mathrm{kg}^{-1}\right)$ were in critical ranges. The concentrations of zinc $\left(1.2 \mathrm{mg} \mathrm{kg}^{-1}\right)$ were in adequate amount while the content of nitrogen (10.12\%) was low (Table 1).

Table 1. chemical analysis of the soil

\begin{tabular}{|c|c|c|}
\hline Soil properties & $\begin{array}{c}\text { Soil depth (6-12 } \\
\text { inch) } \mathrm{mg} \mathrm{kg}^{-1}\end{array}$ & $\begin{array}{c}\text { Adequate ranges } \\
\text { mg kg }^{-1}\end{array}$ \\
\hline Organic matter $\%$ & 0.505 & $>1.29 \%$ \\
\hline $\mathrm{pH}$ & 8.0 & 7 \\
\hline $\mathrm{EC} \mathrm{dS} \mathrm{m}{ }^{-1}$ & 2.05 & 3 \\
\hline $\mathrm{Zn} \mathrm{mg} \mathrm{kg}{ }^{-1}$ & 1.2 & $>1$ \\
\hline Nitrogen (\%) & 10.12 & $>20$ \\
\hline Phosphorus mg kg-1 & 8.2 & $>15$ \\
\hline Potassium mg kg ${ }^{-1}$ & 195 & $>150$ \\
\hline
\end{tabular}


Table 2. Effect of planting dates on the plant growth of gladiolus.

\begin{tabular}{|c|c|c|c|c|c|c|c|c|c|c|c|c|c|c|c|}
\hline $\begin{array}{c}\text { Planting } \\
\text { dates }\end{array}$ & $\begin{array}{c}\text { Days to } \\
\text { germina } \\
\text { tion }\end{array}$ & $\begin{array}{l}\text { Germina } \\
\text { tion } \\
\text { Percenta } \\
\text { ge }(\%)\end{array}$ & $\begin{array}{c}\text { 6-Leaves } \\
\text { Stage }\end{array}$ & $\begin{array}{c}\text { Plant } \\
\text { height }\end{array}$ & $\begin{array}{c}\text { Number } \\
\text { of } \\
\text { leaves }\end{array}$ & $\begin{array}{c}\text { Chloroph } \\
\text { yll } \\
\text { content }\end{array}$ & $\begin{array}{l}\text { Days to } \\
\text { spiking }\end{array}$ & $\begin{array}{l}\text { Spike } \\
\text { length } \\
\text { (cm) }\end{array}$ & $\begin{array}{c}\text { Spike } \\
\text { diameter } \\
(\mathbf{m m})\end{array}$ & $\begin{array}{c}\text { Floret } \\
\text { diameter } \\
(\mathbf{m m})\end{array}$ & $\begin{array}{c}\text { Number } \\
\text { of Florets } \\
\text { spike }^{-1}\end{array}$ & $\begin{array}{c}\text { Fresh } \\
\text { weight } \\
\text { (g) }\end{array}$ & $\begin{array}{c}\text { Dry } \\
\text { weight } \\
\text { (g) }\end{array}$ & $\begin{array}{c}\text { Corm } \\
\text { weight } \\
\text { (g) }\end{array}$ & $\begin{array}{c}\text { Number } \\
\text { of cormel }\end{array}$ \\
\hline $\begin{array}{c}\mathrm{T}_{1} \\
\left(25^{\text {th }} \text { Aug }\right)\end{array}$ & $5.500 \mathrm{a}$ & & & & & & & & & & & & & & \\
\hline $\begin{array}{c}\mathrm{T}_{2}\left(10^{\text {th }}\right. \\
\text { Sep })\end{array}$ & $9.100 \mathrm{~b}$ & $94.66 \mathrm{a}$ & $32.167 \mathrm{a}$ & $115.33 \mathrm{a}$ & $8.02 \mathrm{a}$ & $71.60 \mathrm{a}$ & $40.50 \mathrm{a}$ & $55.66 \mathrm{a}$ & $9.09 \mathrm{a}$ & $97.81 \mathrm{a}$ & $17.16 \mathrm{a}$ & $88.5 \mathrm{a}$ & $28 \mathrm{a}$ & $63.82 \mathrm{a}$ & $63.82 \mathrm{a}$ \\
\hline $\begin{array}{c}\mathrm{T}_{3}\left(25^{\text {th }}\right. \\
\text { Sep })\end{array}$ & $11.93 \mathrm{c}$ & $82.19 b$ & $33.700 \mathrm{a}$ & $111.04 \mathrm{~b}$ & $7.90 \mathrm{a}$ & $67.65 \mathrm{a}$ & $58.93 \mathrm{~b}$ & $55.36 \mathrm{a}$ & $8.94 \mathrm{a}$ & $97.00 \mathrm{a}$ & $15.83 \mathrm{~b}$ & $87.5 \mathrm{a}$ & $27 \mathrm{a}$ & $48.38 \mathrm{c}$ & $48.38 \mathrm{c}$ \\
\hline $\begin{array}{c}\mathrm{T}_{4}\left(10^{\text {th }}\right. \\
\text { Oct })\end{array}$ & $12.73 \mathrm{c}$ & $78.34 \mathrm{c}$ & $44.967 \mathrm{~b}$ & $93.46 \mathrm{c}$ & $7.41 \mathrm{~b}$ & $59.21 \mathrm{~b}$ & $77.20 \mathrm{c}$ & $53.58 \mathrm{a}$ & $8.83 \mathrm{a}$ & $89.67 \mathrm{~b}$ & $14.74 \mathrm{bc}$ & $79 \mathrm{~b}$ & $24.2 \mathrm{~b}$ & $52.65 \mathrm{~b}$ & $52.65 \mathrm{~b}$ \\
\hline $\begin{array}{c}\mathrm{T}_{5}\left(25^{\text {th }}\right. \\
\text { Oct })\end{array}$ & $13.66 \mathrm{~d}$ & $71.39 \mathrm{~d}$ & $67.467 \mathrm{c}$ & $90.30 \mathrm{c}$ & $7.10 \mathrm{~b}$ & $56.37 \mathrm{~b}$ & $89.33 \mathrm{~d}$ & $48.41 \mathrm{~b}$ & $8.26 \mathrm{~b}$ & $73.51 \mathrm{c}$ & $13.83 \mathrm{~cd}$ & $75 \mathrm{c}$ & $20.5 \mathrm{c}$ & $54.49 \mathrm{~b}$ & $54.49 \mathrm{~b}$ \\
\hline $\begin{array}{l}\mathrm{T}_{6}\left(10^{\text {th }}\right. \\
\text { Nov })\end{array}$ & $20.80 \mathrm{e}$ & $64.68 \mathrm{e}$ & $75.667 \mathrm{~d}$ & $88 \mathrm{~d}$ & $6.53 \mathrm{c}$ & $50.69 \mathrm{c}$ & $95.83 \mathrm{e}$ & $43.91 \mathrm{c}$ & $7.55 \mathrm{c}$ & $67.32 \mathrm{~d}$ & $12.75 \mathrm{~d}$ & $67.5 \mathrm{~d}$ & $17.5 \mathrm{c}$ & $59.99 \mathrm{ab}$ & $59.99 \mathrm{ab}$ \\
\hline
\end{tabular}




\subsection{Growth Parameters}

\subsubsection{Days to Germination}

The treatments comprising of different planting dates have a significant effect on number of days taken by gladiolus corm to germinate. The results indicated significant superiority of $T_{1}$ with only 5.5 days followed by $T_{2}$ with 9.10 days on all the treatments. $\mathrm{T}_{6}$ occupy the bottom position with 20.80 days in the ranked order of treatments. $T_{1}$ plantation vanished after germination due to severe environmental conditions therefore only five treatments are discussed in following text (Table 2). A strong correlation was observed between temperature and days to sprouting as shown in Fig 1A.

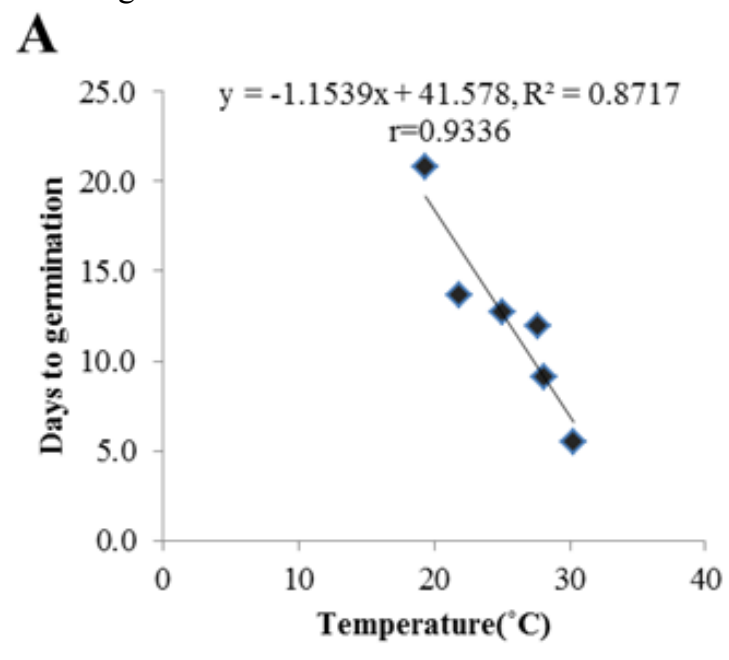

Figure 1(A). Growth parameyrers of Gladiolus grandiflorus

\subsubsection{Germination Percentage (\%)}

Among the treatments maximum sprouting percentage was recorded in $\mathrm{T}_{2}$ with $94.66 \%$ germination followed by $\mathrm{T}_{3}$ $82.19 \%$ germination on all the treatments. $\mathrm{T}_{6}$ occupy the bottom position with only $64.68 \%$ germination in the ranked order of treatments. The correlation value $(0.971)$ shows strong positive relation between sprouting percentage and temperature as shown in Fig 1B.

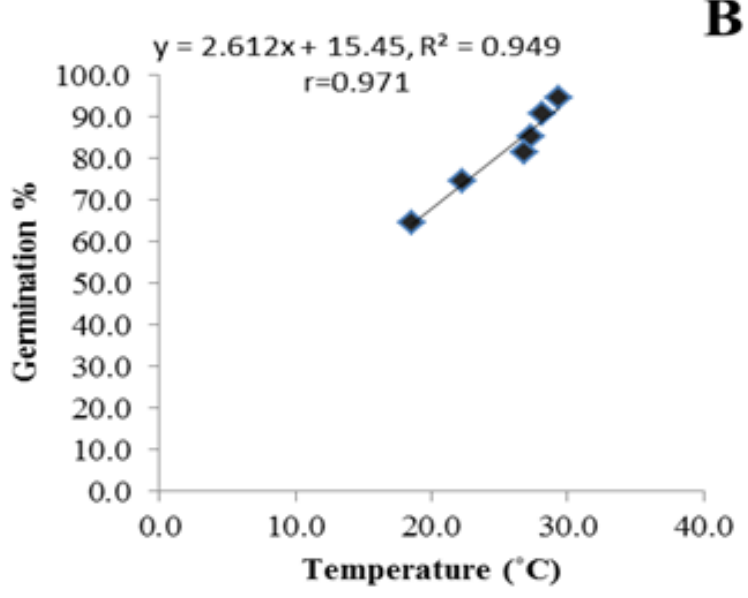

Figure 1(B). Growth parameyrers of Gladiolus grandiflorus

\subsubsection{Days to 6-Leaves Stage}

Collected data regarding days to 6-leaves stage was subjected to statistical analysis and results obtained depict highly significant difference in variance of treatments, interactive effect of treatments and cultivars. Means indicated significant superiority of T2 with only 32.167 days followed by T3 with 33.70 days on all the treatments. T6 occupy the bottom position with 75.66 days in the ranked order of treatments. A strong correlation between days to six leaves stage and temperature was observed (Fig 1C).

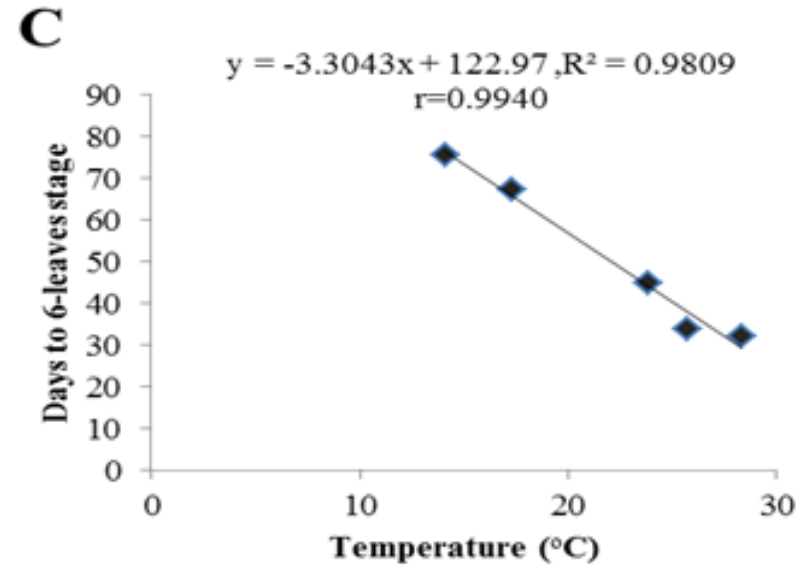

Figure 1(C). Growth parameyrers of Gladiolus grandiflorus

\subsubsection{Plant Height (cm)}

Among the treatments, maximum plant height $(115.33 \mathrm{~cm})$ was recorded in $\mathrm{T}_{2}$ followed by $\mathrm{T}_{3}$ with $111.04 \mathrm{~cm}$. $\mathrm{T}_{6}$ occupy the bottom position with $88 \mathrm{~cm}$ in the ranked order of treatments. Maximum temperature was recorded during plantation on $10^{\text {th }}$ Sep. and $25^{\text {th }}$ Sep. with $26.35^{\circ} \mathrm{C}$ and $25.08^{\circ} \mathrm{C}$ respectively while lowest temperature $15.85^{\circ} \mathrm{C}$ was recorded during $10^{\text {th }}$ Nov. plantation. In this experiment a strong correlation was observed between the plant height and temperature (Fig 1D).

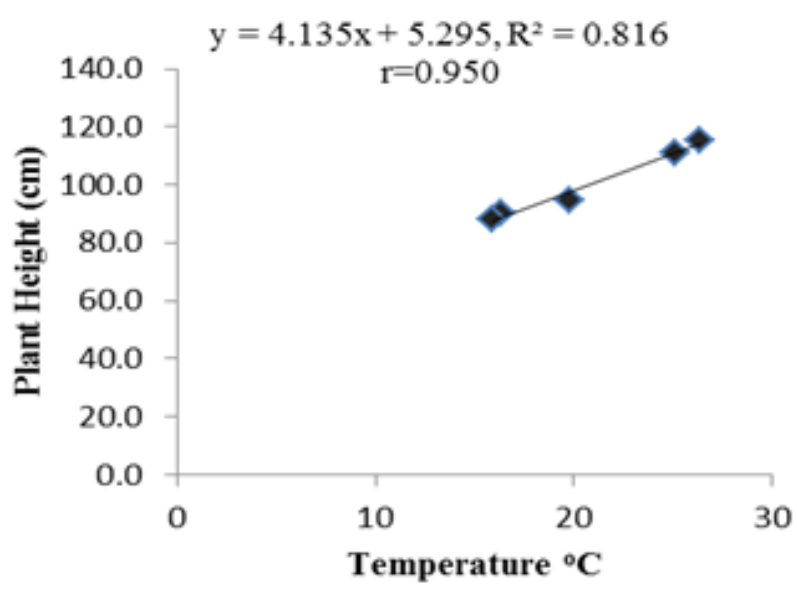

Figure 1(D). Growth parameyrers of Gladiolus grandiflorus 
All the observations were processed statistically and results obtained depict highly significant effects in variance of treatments whereas cultivars and variety $\mathrm{x}$ treatments interaction was found non-Significant. Means indicated significant superiority of $T_{2}$ with 8.02 leaves and $T_{3}$ with 7.93 leaves on all other treatments. Minimum leaves (6.53) were recorded in $\mathrm{T}_{6}$. Maximum leaves were observed at $26.35^{\circ} \mathrm{C}$ and $25.08^{\circ} \mathrm{C}$ respectively. In fact, more number of leaves was produced in plants with greater height and well developed structure. A strong correlation was observed between number of leaves and temperature (Fig 1E).

\section{$\mathbf{E}$}

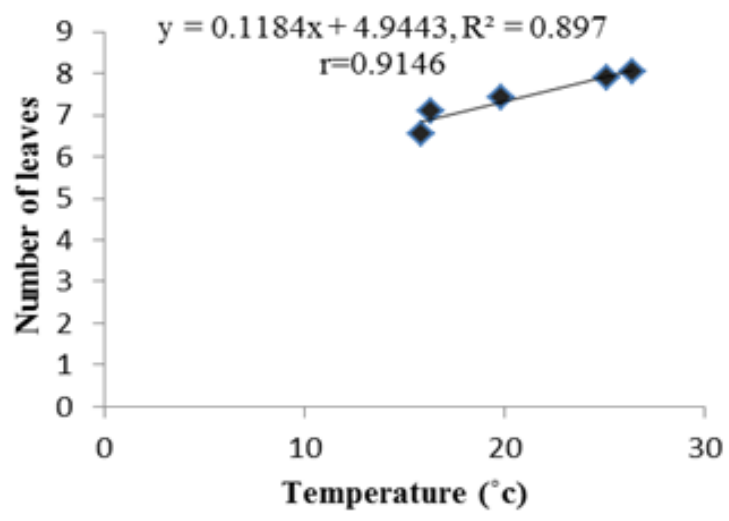

Figure 1(E). Growth parameyrers of Gladiolus grandiflorus

\subsubsection{Chlorophyll content}

Among the treatments, maximum chlorophyll contents 71.60 were recorded in $T_{2}$ followed by $T_{3}$ with 67.65 on all the treatments. $\mathrm{T}_{6}$ occupy bottom position with 50.69 in the ranked order of treatments. Maximum temperature was recorded during plantation on $10^{\text {th }}$ Sep. and $25^{\text {th }}$ Sep. with $26.35^{\circ} \mathrm{C}$ and $25.08^{\circ} \mathrm{C}$ respectively while lowest temperature $15.85^{\circ} \mathrm{C}$ was recorded during $10^{\text {th }}$ Nov. plantation. Chlorophyll contents are one of the most important criteria to determine the health of the plant, because chlorophyll contents are directly related to physiological activities to manufacture food. In this experiment highly positive correlation was observed between temperature and chlorophyll contents (Fig 1F).

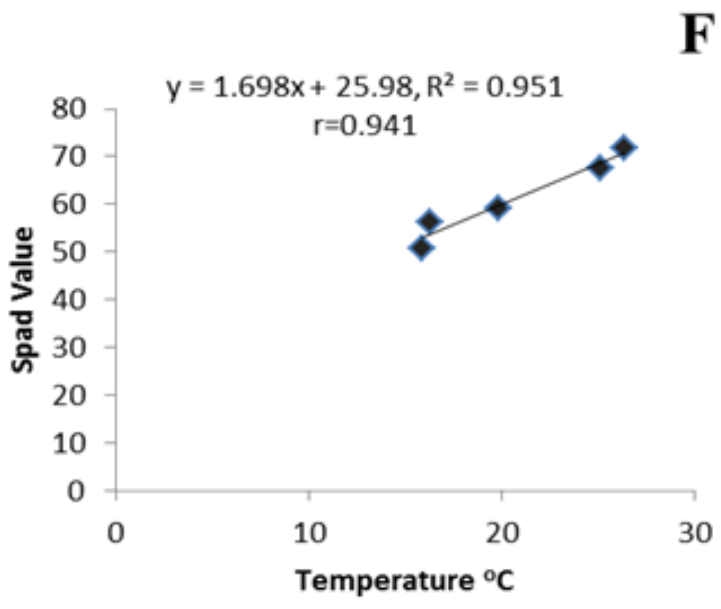

Figure 1(F). Growth parameyrers of Gladiolus grandiflorus

\subsection{Flowering Parameters}

\subsubsection{Days to Spiking}

Means indicated significant superiority of $T_{2}$ with 40.50 days and $T_{3}$ with 58.33 days on all the treatments. $T_{6}$ occupy bottom position with 95.83 days in the ranked order of treatments. Maximum temperature was recorded during plantation on $10^{\text {th }}$ Sep. and $25^{\text {th }}$ Sep. with $26.35^{\circ} \mathrm{C}$ and $25.08^{\circ} \mathrm{C}$ respectively while lowest temperature $15.85^{\circ} \mathrm{C}$ was recorded during $10^{\text {th }}$ Nov. plantation. In this experiment a strong correlation was observed between temperature and days to sprouting (Fig. 2A).

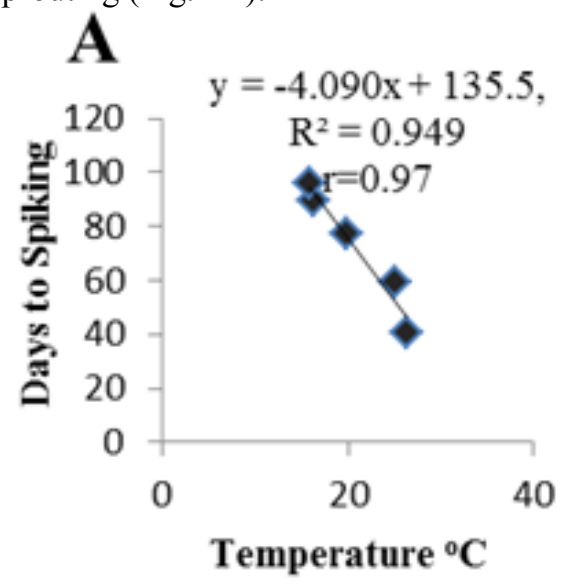

Figure 2(A). Growth parameyrers of Gladiolus grandiflorus

\subsubsection{Spike Length $(\mathrm{cm})$}

Spike length showed highly significant difference in variance of treatments, interactive effect of treatments and cultivars. Among the treatments, maximum spike length $55.66 \mathrm{~cm}$ was recorded in $T_{2}$ followed by $T_{3}$ with $55.36 \mathrm{~cm}$ on all the treatments. $\mathrm{T}_{6}$ occupy bottom position with 43.91 $\mathrm{cm}$ in the ranked order of treatments. Maximum temperature was recorded during plantation on $10^{\text {th }}$ Sep. and $25^{\text {th }}$ Sep. with $26.35^{\circ} \mathrm{C}$ and $25.08^{\circ} \mathrm{C}$ respectively while lowest temperature $15.85^{\circ} \mathrm{C}$ was recorded during $10^{\text {th }}$ Nov. plantation (Fig. 2B).

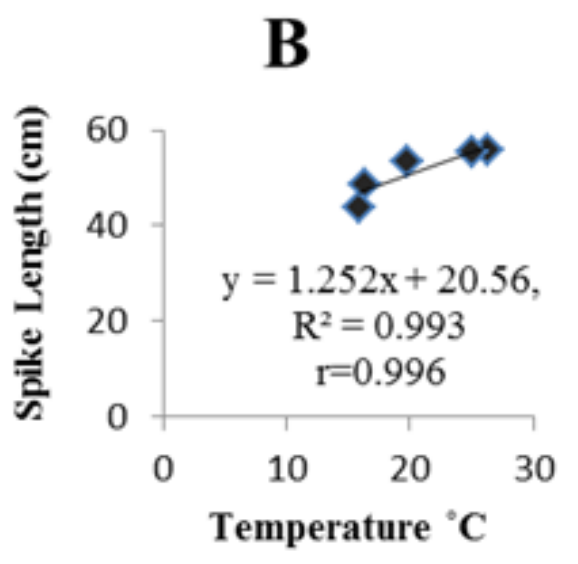

Figure 2(B). Growth parameyrers of Gladiolus grandiflorus

3.3.3 Number of Florets spike ${ }^{-1}$ 
Among the treatments, maximun number of florets (17.16) was recorded in $\mathrm{T}_{2}$ followed by $\mathrm{T}_{3}$ with 15.83 florets. Least number of florets (12.74) was noticed in $\mathrm{T}_{6}$. Maximum temperature was recorded during plantation on $10^{\text {th }} \mathrm{Sep}$. and $25^{\text {th }}$ Sep. with $26.35^{\circ} \mathrm{C}$ and $25.08^{\circ} \mathrm{C}$ respectively while lowest temperature $15.85^{\circ} \mathrm{C}$ was recorded during $10^{\text {th }}$ Nov. plantation. A strong correlation between temperature and number of florets was observed (Fig. 2C).

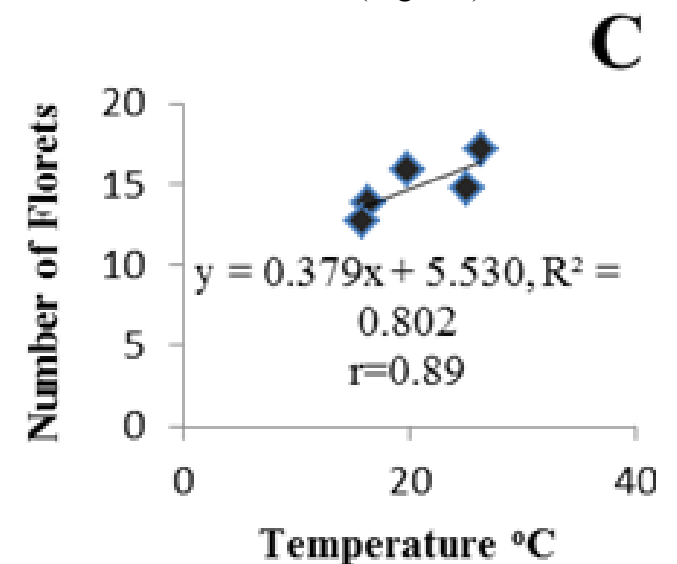

Figure 2(C). Growth parameyrers of Gladiolus grandiflorus

\subsubsection{Fresh Weight of Spike (g)}

The results revealed highly significant differences in fresh weight of spike among two cultivars of gladiolus. Variety $\times$ treatments interaction was found non-Significant and the effect of treatments was found significant. Means indicated superiority of $\mathrm{T}_{2}$ in fresh weight of spike with $88.5 \mathrm{~g}$ followed by $\mathrm{T}_{3}$ which got second best position with $87.5 \mathrm{~g}$ over rest of the treatments whereas, $\mathrm{T}_{6}$ occupy bottom position with $67.5 \mathrm{~g}$ in the ranked order of treatments. Maximum temperature was recorded during plantation on $10^{\text {th }}$ Sep. and $25^{\text {th }}$ Sep. with $26.35^{\circ} \mathrm{C}$ and $25.08^{\circ} \mathrm{C}$ respectively while lowest temperature $15.85^{\circ} \mathrm{C}$ was recorded during $10^{\text {th }}$ Nov. plantation. A positive correlation between temperature and fresh weight of spike was observed (Fig. 2E).

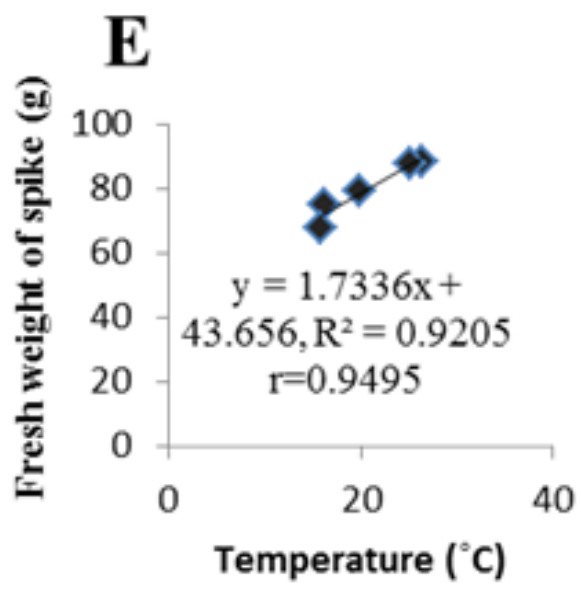

Figure 2(E). Growth parameyrers of Gladiolus grandiflorus

\subsubsection{Dry Weight of Spike (g)}

The results regarding effect of different planting dates on dry weight of spike of two cultivars of gladiolus indicated superiority of $\mathrm{T}_{2}\left(10^{\text {th }}\right.$ Sep.) in dry weight of spike with $28 \mathrm{~g}$ followed by $\mathrm{T}_{3}\left(25^{\text {th }} \mathrm{Sep}\right.$.) which got second best position with $27 \mathrm{~g}$ over rest of the treatments whereas, $\mathrm{T}_{6}$ occupy bottom position with $17.5 \mathrm{~g}$ in the ranked order of treatments. Maximum temperature was recorded during plantation on $10^{\text {th }}$ Sep. and $25^{\text {th }}$ Sep. with $26.35^{\circ} \mathrm{C}$ and $25.08^{\circ} \mathrm{C}$ respectively while lowest temperature $15.85^{\circ} \mathrm{C}$ was recorded during $10^{\text {th }}$ Nov. plantation. A positive correlation between temperature and dry weight of spike was observed (Fig. 2F).

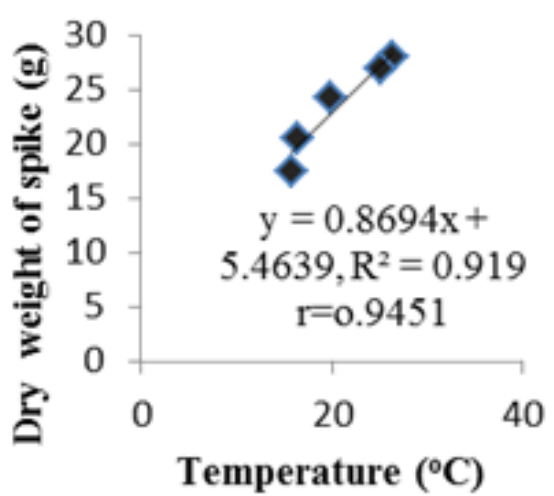

Figure 2(F). Growth parameyrers of Gladiolus grandiflorus

\subsubsection{Corm Diameter $(\mathrm{cm})$}

Among the treatments maximum corm diameter $(6.19 \mathrm{~cm})$ was recorded on $\mathrm{T}_{2}$ followed by $\mathrm{T}_{6}$ with $(5.96 \mathrm{~cm}) . \mathrm{T}_{3}$ got the bottom position with $5.21 \mathrm{~cm}$ in the ranked order of treatments. Maximum temperature $21.6^{\circ} \mathrm{C}$ was recorded during plantation done on $10^{\text {th }}$ Nov. followed by $10^{\text {th }} \mathrm{Sep}$. plantation with $19.4^{\circ} \mathrm{C}$ while lowest temperature $14.75^{\circ} \mathrm{C}$ was recorded during $25^{\text {th }}$ Sep. (Fig. $2 \mathrm{G}$ ).

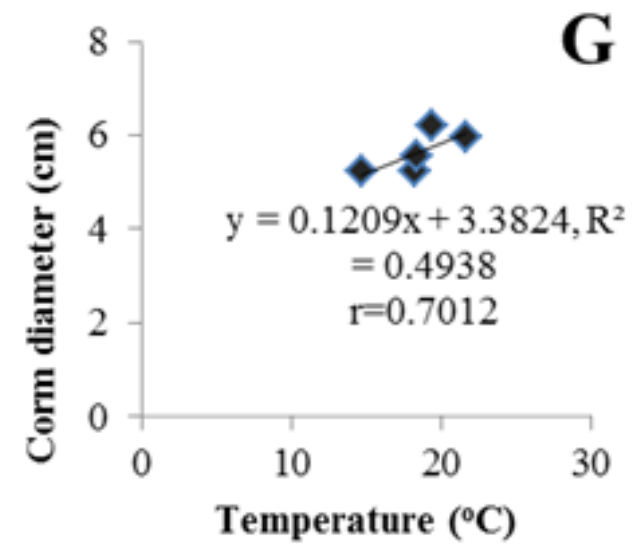

Figure 2(G). Growth parameyrers of Gladiolus grandiflorus

\subsubsection{Corm weight (g)}

The results of different planting dates on corm weight of two cultivars of gladiolus indicated significant superiority of $\mathrm{T}_{2}$ with $63.82 \mathrm{~g}$ followed by $\mathrm{T}_{6}$ with $59.99 \mathrm{~g}$ on other treatments. $\mathrm{T}_{3}$ occupy the bottom position with $48.38 \mathrm{~g}$ in the ranked order of treatments. Maximum temperature $21.6^{\circ} \mathrm{C}$ 
was recorded during plantation done on $10^{\text {th }}$ Nov. followed by $10^{\text {th }} \mathrm{Sep}$. plantation with $19.4^{\circ} \mathrm{C}$ while lowest temperature $14.75^{\circ} \mathrm{C}$ was recorded during $25^{\text {th }} \mathrm{Sep}$. plantation. A positive correlation between temperature and corm weight was also observed (Fig. 2H).

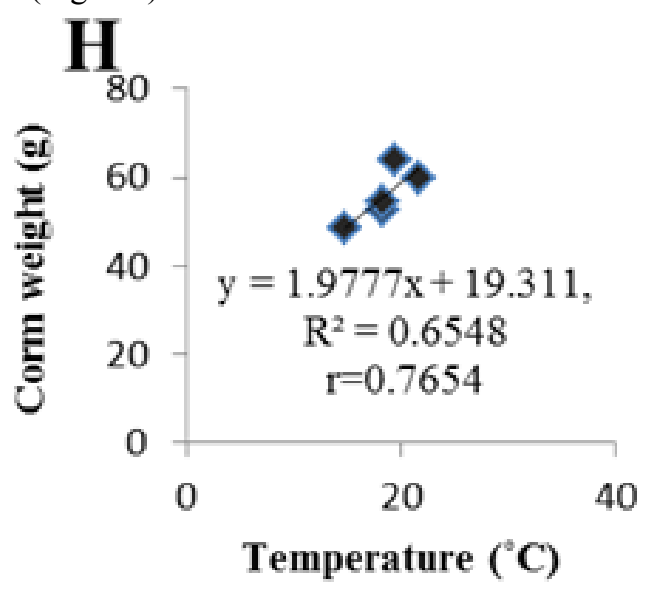

Figure 2(H). Growth parameyrers of Gladiolus grandiflorus

\subsubsection{Number of Cormels}

Among the treatments maximum number of cormels (33.83) was recorded in $\mathrm{T}_{6}$ followed by $\mathrm{T}_{5}$ with (33.16). $\mathrm{T}_{3}$ got the bottom position with minimum number of cormels (18.42) in the ranked order of treatments. Maximum temperature $21.6^{\circ} \mathrm{C}$ was recorded during plantation done on $10^{\text {th }}$ Nov. followed by $10^{\text {th }} \mathrm{Sep}$. plantation with $19.4^{\circ} \mathrm{C}$ while lowest temperature $14.75^{\circ} \mathrm{C}$ was recorded during $25^{\text {th }}$ Sep. plantation. A positive correlation between temperature and number of cormels was also observed (Fig. 2I).

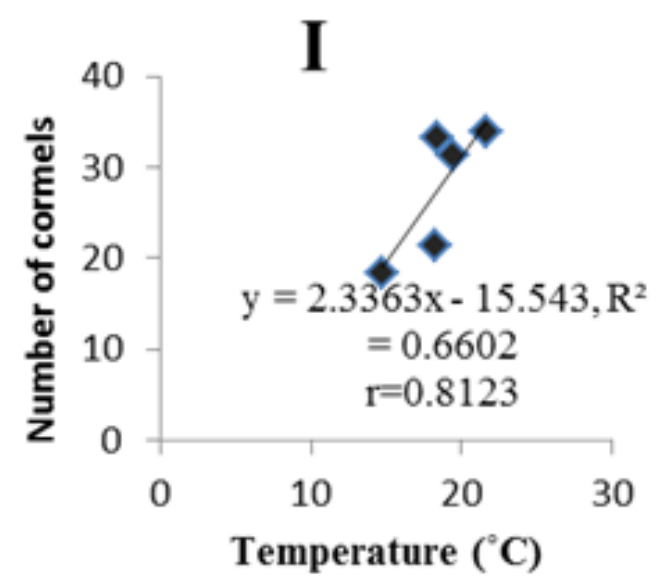

Figure 2(I). Growth parameyrers of Gladiolus grandiflorus

Finally it can be concluded that different planting dates and temperatures (weather difference) have a significant effect on the growth of gladiolus. Proper planting date not only reduce the production cost by reducing the crop time and thus increasing cost benefit ratio but also produce elite flowers with increased market value. The results of the experiment can also be used in scheduling and round the season production because all the sowing dates produce marketable size spikes.

\section{Discussion}

Early germination at high temperature is also reported that elevated temperature within the appropriate range results in early sprouting of corms [8]. A strong correlation was observed between temperature and days to sprouting as shown in Fig 1A.The correlation value (0.971) shows strong positive relation between sprouting percentage and temperature as shown in Fig 1. The results are in line with the findings of Carpenter [10] who reported that temperature between $20^{\circ} \mathrm{C}$ to $25^{\circ} \mathrm{C}$ promoted germination to $97 \%$ in gladiolus. A strong correlation between days to six leaves stage and temperature was observed that are in conformity with the findings of Halevy [11] that plantings at higher temperature will take 37 to 45 days to reach 6-leaves stage while low temperature would take 52 to 59 days (Fig 1C). The increase in plant height of gladiolus at high temperature is also reported by Gursan [12] that plant height of gladiolus under warm temperatures was $113 \mathrm{~cm}$ as compared to $77 \mathrm{~cm}$ panted under lower temperatures. In this experiment a strong correlation was observed between the plant height and temperature (Fig 1D). More number of leaves was produced in plants with greater height and well developed structure. A strong correlation was observed between number of leaves and temperature (Fig 1E). The results are in line with the findings of Bose [13] who reported maximum number of leaves in plants grown under warmer temperature and long day lengths. Chlorophyll contents are one of the most important criteria to determine the health of the plant, because chlorophyll contents are directly related to physiological activities to manufacture food. The results are in line with the findings of Goldman [14] who reported increase in chlorophyll and photosynthetic activity at high temperature. In this experiment highly positive correlation was observed between temperature and chlorophyll contents (Fig 1F).

Early spiking at high temperature is also reported by Halevy [11] who stated that gladiolus flowered more rapidly under warm temperatures regardless of photoperiod. The results are in line to the finding of McCalla [15] who reported increase in the number of days to inflorescence formation in gladiolus under lower temperatures. Maximum temperature was recorded during plantation on $10^{\text {th }} \mathrm{Sep}$. and $25^{\text {th }}$ Sep. with $26.35^{\circ} \mathrm{C}$ and $25.08^{\circ} \mathrm{C}$ respectively while lowest temperature $15.85^{\circ} \mathrm{C}$ was recorded during $10^{\text {th }}$ Nov. plantation. Shortening of gladiolus spike at low temperature is also reported by [15]. In this experiment highly positive correlation was observed between temperature and spike length (Fig. 2B). The Increase in number of florets at high temperature is also reported by Larson [16] who found more number of florets per plant, when planting was done during hot summer months. A strong correlation between temperature and number of florets was observed (Fig. 2C). A positive correlation between temperature and fresh weight of spike was observed (Fig 2E). The results are in line with the findings of Ko [17] who reported increased fresh weight of chrysanthemum flower at $17^{\circ} \mathrm{C}$ as compared to $21^{\circ} \mathrm{C}$ in a 
winter greenhouse experiment. A positive correlation between temperature and dry weight of spike was observed (Fig 2F). The results are in line with the findings of Bose [18] who reported increased dry matter production at high temperature may be attributed to greater accumulation of photosynthates by vegetative parts in gladiolus. A positive correlation between temperature and corm diameter was also observed (Fig 2G). The results are in line with the findings of Parker [19] who reported increase in corm diameter at high temperature in part to the production of more photosynthates. A positive correlation between temperature and corm weight was also observed (Fig $2 \mathrm{H})$. The results are in line with the findings of Shillo [20] who reported increase in corm weight at high temperature and long day lengths. A positive correlation between temperature and number of cormels was also observed (Fig 2I). The results are in line with the findings of 21 who reported increase in gladiolus cormel production at slightly high temperature.

\section{REFERENCES}

[1] F. Rehman An article on Rose cut flowers, farming outlook publishers, Pakistan, 2004.

[2] J. M. Jenkins, R. D. Milholland, J. P. Lilly, M. K. Beute. Commrcial gladiolus production in North Carline, NC Agric Ext Circ1, 44: 1-34, 1970.

[3] R. S. Saini, A. K. Gupta,R. Yamdagni. Effect of planting time on the flowering and cormel production of gladiolus (Gladiolus floribundus L.), South-Indian-Horticultural Sciences, Vol.31, No.3, 294-299, 2010.

[4] T. Riaz, S. N. Khan, A. Javaid. Scenario of gladiolus production in Punjab, Pakistan. Pakistan Journal of Botany, Vol.39, No.7, 2389-2393, 2007.

[5] M. Aftab, G. Shabbir, A. Mahmood. Production of high quality bulbous flowers in Pothwar. Prospects of Horticulture Industry in Pakistan, International symposium. University of Agriculture Faisalabad, 221-223, 2007.

[6] M. Zubair, F. K. Wazir, S. Akhtar,G. Ayub. Planting dates affect floral characteristics of gladiolus under the soil and climatic conditions of Peshawar, Pakistan Journal of Biological Sciences, Vol.9, No.9, 1666-1676, 2006.

[7] V. N. Dod, K. T. Sadawarte, L. V. Kulwal, S. W. Vaidya. Effect of different dates of planting and size of corm on growth and flower yield of Gladiolus. Panjabrao deshmukh krishi vidyapeeth Research Journal, Vol.13, No.2, 164-165,
1989.

[8] H. T. Hartmann, W. J. Flocker, A. M. Kofranek, Plant science. Growth, development and utilization of cultivated plants, Plant Science, 25-30, 1981.

[9] R. G. D. Steel, J. H. Torrie, D. A. Dicky. Principles and procedures of statistics. A biological approach, McGraw Hill Book Co., New York. 1997.

[10] E. Carpenter, M. P. Damann,, R. E. Lyons. Juvenility and photoperiodic flowering requirements of Chrysanthemum grown under short- and long-day conditions, Journal of American Horticultural society, Vol.120, 241-245, 1995.

[11] A. H. Halevy. Gladiolus in the Handbook of Flowering, Vol. III, CRC Press. Boca Raton, 1985.

[12] K. Gursan, Growing Gladiolus, Atatürk Horticultural Research Institute1, Yalova, 1990.

[13] T. K. Bose, B. K. Jana, T. P. Mukhpadhyay, A note on the effect of day length on growth and flowering in Hippeastrum, Indian Journal of Horticulture, Vol.38, 110-112, 1981.

[14] J. C. Goldman, Temperature effects on phytoplankton culture in continous culture. Journal of Experimental marine Boilogy, Vol.27, 161-165, 1980.

[15] A. G. McCalla, J. R. Weir, K. W. Neatby. Effects of temperature and sunlight on the rate of elongation of stems of maize and gladiolus. Canadian Journal of Research , Vol.17, No.11, 388-409, 2011.

[16] R. A. Larson. Introduction to Floriculture, 2nd ed. Acad. Press, San Diego, California, 1991.

[17] J. Y. Ko, S. K. Kim,N. Y. Um, J. S. Han, K. K. Lee. Planting times and corm grades of gladiolus gandavensis for retarding culture in high land. Journal of Agricultural Sciences, Vol.36, No.1, 430-434, 1994.

[18] U. S. Bose, S. K. Tripathi. Effect of micronutrients on growth, yield and quality of tomato cv. Pusa Ruby, Plant sciences feed, Vol.12, 61-64, 1996.

[19] M. W. Parker, H. A. Borthwick. Day-length proved vital factor in gladiolus flowering, Florirts Exchange, Vol.117, No.26, 38-40, 1980.

[20] R. Shillo, A. H. Halevy. The effect of various environmental factors on flowering of gladiolus. Scientia Horticulturae, Vol.4, 147-155, 2005.

[21] M. A. Laskar, B. K. Jana. Effect of planting time and size of corms on plant growth, flowering and corm production of Gladiolus. Indian Agriculture, Vol.38, 89-97, 1994. 